\title{
Complexity, continuity, and strategic management of buyer-supplier relationships from a network perspective
}

\author{
Martin Pech ${ }^{1}$ (D), Drahoš Vaněček ${ }^{2}$ (D), \\ Jaroslava Pražákováa iD
}

\begin{abstract}
PURPOSE: Current research seeks to create an economic model that connects strategic management and network theory. However, most theoretical models do not provide empirical evidence of network relationships' real structure and attributes. The purpose of the paper is to explore the relation between enterprise characteristics and the characteristics of buyer-supplier relationships in supply chain networks. We are specifically interested in business relationships in networks with respect to the various enterprises' sizes and sectors of industry. The subject of our research was characteristics, such as network relationship complexity, continuity of relationships, and strategic management in networks. The paper summarizes the results of an empirical study on buyer-supplier networks and accentuates the importance of developing and fostering business collaboration for strategic management. METHODOLOGY: We conducted the questionnaire research in 2016-2019 on 360 enterprises from the Czech Republic. We selected the research sample based on the non-probability purposive sampling method. The members of the research team collected data from an online survey and personal visits to enterprises. The statistical analysis of hypotheses is based on the frequency of managers' answers. To evaluate results, a two-proportion Z-Test is used for comparing different categories of enterprises according to their enterprise size or prevailing sector of the industry. FINDINGS: The main results show that the differences between enterprises involved in the buyer-supplier structures lie mainly in their size. The survey did not identify

\footnotetext{
1 Martin Pech, Ing., Ph.D., Senior Assistant Professor, University of South Bohemia in České Budějovice/Faculty of Economics/Department of Management, Studentská 13, 37005 České Budějovice, Czech Republic, email: mpechac@ ef.jcu.cz (ORCID ID: https://orcid.org/0000-0002-0807-3613).

2 Drahoš Vaněček, Prof., Ing., CSc., Professor, University of South Bohemia in České Budějovice/Faculty of Economics/ Department of Management, Studentská 13, 37005 České Budějovice, Czech Republic, email: dvanecek@ef.jcu.cz (ORCID ID: https://orcid.org/0000-0003-2767-2686)

3 Jaroslava Pražáková, Ing., Ph.D., Senior Assistant Professor, University of South Bohemia in České Budějovice/Faculty of Economics/Department of Accounting and Finances, Studentská 13, 37005 České Budějovice, Czech Republic, email: smoloj@ef.jcu.cz (ORCID ID: https://orcid.org/0000-0003-3676-0602).
} 
differences between industry sectors. The findings show that the complexity of networks in the Czech Republic is not high in terms of the number of suppliers or involvement in many supply networks. The continuity of relationships with partners in buyer-supplier networks is relatively long-term oriented. Long-term partnerships reflect the higher quality of relationships and support future integration. However, large enterprises prefer to build contracts for shorter or longer periods. An overall decentralization strategy characterizes the strategic management of buyer-supplier networks. This finding means dividing competencies such as planning, managing, sourcing, decision-making, transporting (delivering) among more enterprises. IMPLICATIONS FOR THEORY AND PRACTICE: The paper provides an insight into understanding how the buyer-supplier network functions. The theory's implication builds on the connection of supply chain management and strategic management from the network perspective. Supply chain management is viewed as a part of strategic management, and the synthesis of both research areas opens an innovative view to business theory. ORIGINALITY AND VALUE: The paper's principal value is the connection between contemporary ideas of strategic management and supply chain management. The synthesis of supply chain management and network approach enhances strategic management theory.

Keywords: network, buyer-supplier relationships, strategic management, complexity, continuity, supply chain management

\section{INTRODUCTION}

Our world's reality characterizes uncertainty, complexity, continuity, change, the informality of relationships, and interaction between networks. Strategic management's primary role in the new era is to connect everything into a massive web of networks of different levels of relationships. Resources and activities are shared, markets expand, and risk costs are reduced. Networks bring together businesses into a vast web of interdependent relationships. The network society's main characteristic is the networked connection between the micro and macro environment (Castells, 2010). Networks come in many forms and include supply networks such as transport, logistics, communication, and energy networks and abstract economic, financial, and social, and knowledge networks. Networks have complex structures that are often hidden, as our current understanding of these systems is uncertain.

Business relationships between enterprises are a strategic issue and play a key role in business strategy (Tikkanen \& Halinen, 2003). The previous strategic management research mostly views the development and implementation of a strategy as an internal management challenge to cope with internal and external forces. However, it focuses less on the relationship between the network members' strategy and the network level's strategy beyond the focal enterprise's influence or control. Besides, 
traditional approaches do not explain how and why organizations engage in relationships and how they are managed and coordinated. It is necessary to develop and create new concepts related to applying the network approach to strategic management. However, network theory still misses appropriate theoretical and empirical support (Krzakiewicz \& Cyfert, 2013).

According to Moller and Halinen (1999), the management of buyersupplier relationships is not a new research area but becomes a "hot topic" from a network perspective. Industry 4.0 technologies in global networks move traditional relations between buyer-supplier to a supply chain network of connections in which data are aggregated in disseminated platforms (Szozda, 2017). Digitization, robotics, and artificial intelligence (Vrchota \& Pech, 2019) form the basis for a new economic system based on cyberspace and market changes on the network (Rifkin, 2000). It means horizontal integration across the value creation network, in-depth end-toend engineering across the entire product life cycle, and vertical integration of management and manufacturing information systems (Wang, Wan, $\mathrm{Li}$, \& Zhang, 2016). New technology enables multiple parallel connections of customers, suppliers, and business partners (Simangunsong, 2015). Managing multiple chains is incredibly more complex, and the optimization requires knowledge of supply network characteristics. In the last two decades, the supply chain strategy and its role in supply chain management have been studied (Hasani \& Khosrojerdi, 2016). However, the coordination of links in the final product's supply chain networks remains a problem due to enterprises' different characteristics. From this perspective, supply chain strategy is a part of a network approach to strategic management.

Literature sources state that the global economy is based on networks. However, most publications that are usually using aggregated data or theoretic models, provide empirical evidence of the complexity, continuity, or strategic management of these relationships indirectly only. Thus, our study uses empirical research and it tries to answer these research questions: Differ enterprises in length of cooperation in buyer-supplier networks according to the enterprises size or are important their sector of industry characteristics? Are enterprise size and sector of industry characteristics important for participation and complexity of supply chain networks? Is the managing role and type of management of the supply chain network determined by enterprise size and sector of industry characteristics? The contemporary characteristics such as network complexity, continuity, and strategic management were analyzed. Having a more comprehensive insight into a supply chain's aspects would yield useful information about how the buyer-supplier network works. The objective of the paper is to analyze relations between characteristics of 
enterprises and buyer-supplier networks from a strategic management and network perspective point of view.

\section{LITERATURE REVIEW}

The literature review conceptualizes the main constructs and examines a research model. Further, the research questions and hypotheses are determined.

\section{The conceptualization of constructs and a research model}

The market can be understood as a network where nodes are business units - production and service enterprises and the relationships between them are links (Håkansson \& Ford, 2002). The network approach is based on the assumption that economic activities are influenced by the social context (relational and structural) in which they are embedded. Relational embeddedness refers to a shared understanding of strongly tied network members' behaviors. Structural embeddedness is related to the information role of the network's position (Gulati, 1998). Current knowledge indicates more types of embeddedness of networks such as knowledge (Sudolska \& Lis, 2014), technology (González-López, 2012), financial, political, and cultural (Klincewicz, 2012). The interconnectedness of business relationships emerged due to the existence of an aggregated structure, a form of network organization (Håkansson \& Snehota, 1995). Thus, networks are multiple organizations that interact directly or indirectly, based on alliance agreements. Networks can exist between enterprises, but they do not replace enterprises. They complement the activities that companies coordinate internally. The network diversity expresses the strength of individual connections, network size, modularity, membership mix, network management methods, or tendency to form clusters. The networks vary in density, the existence of structural holes, structural equivalence, and the difference between core versus peripheral firms (Gulati, Nohria, \& Zaheer, 2000).

According to Tikkanen and Halinen (2003), the classic strategic management theories fail to explain enterprises interconnected within the network. Therefore, there is a need to study strategy and management from a new network perspective. The contemporary world of networks is difficult to describe, analyze, and explain using the traditional competitive strategy paradigm (Jarillo, 1988). Despite various strategic and network approaches, the network perspective in strategic management is still relatively fragmented (Koch \& Windsperger, 2017). The industrial network and strategic network 
theory are mostly considered as the base for this new approach. The industrial network theory highlights the relation of a strategy to the network environment regarding business relations (Tikkanen \& Aino, 2003). Strategic network theorists emphasize the role of network relations as a resource (competence or knowledge) of competitive advantage. The network research models related to management are classified by Światowiec-Szczepańska and Kawa (2018) into three dimensions: homogenous and heterogeneous models, flow and architecture models, and models based on the emergent or intentional origin of networks. These models are mainly based on symbolic, graphical (social network analysis theory), or mathematical (graph theory) approaches to network theory.

In the literature, networks are in general conceived as alliances and relationships between enterprises. Barczak (2015) distinguishes networks into complex networks, networks within the organization, and networks between organizations. The networks consist of closer business cooperation with suppliers within the supply chain, customers, or other enterprises. Ketchen and Giunipero (2004) show that the main contributions of strategic management to supply chain management are a resource-based (knowledge-based) view, an agency and institutional theory, and an emphasis on enterprise performance. On the other side, supply chain management offers new analysis levels (Harland, 1996) and new organization types to management (Croom, Romano, \& Giannakis, 2000). Some supply chains fulfill organizations' main characteristics - participants, social structure, goals, and technology. Enterprise-centric and network-centric paradigms have some mutual technological, organizational, and managerial aspects described by Akyuz \& Gursoy (2020). It means that supply chain management is an enterprise function supporting the strategy and is a crucial part of the strategy (Hult, Ketchen, \& Arrfelt, 2007). Supply chain management brings strategy implementation and a holistic approach from the network perspective (Venus, 2014).

The network perspective leads to several important questions for managers, as follows. The level of complexity, symmetry/asymmetry, continuity/discontinuity, and formality/ informality is considered as structural characteristics of business relationships in networks, particularly in customer-supplier relationships (Håkansson \& Snehota, 1995). Our paper focuses on some of these characteristics, namely, complexity (relational perspective), continuity (long-term perspective), and further, we expanded the research topic to include management (strategic view). The symmetry/asymmetry characteristic is considered a part of the strategic view of network management. We analyzed these characteristics according to enterprise size (A) and sector of industry (B). The proposed model of research is presented in Figure 1. The research model divides the researched 
area according to the level of business relationships (length of relationships, number of suppliers) and the level of network characteristics (roles, types of management, and engagement in networks). This division indicates the relationship of research areas to the network and the buyer-supplier relationship as intended by Håkansson \& Snehota (1995). Based on this research model, we proposed research hypotheses $\mathrm{H} 1 \mathrm{~A}, \mathrm{H} 1 \mathrm{~B}$ (continuity of relationships), H2A, H2B, H3A, H3B (complexity of relationships), H4A, $\mathrm{H} 4 \mathrm{~B}$ (role in supply chain networks), and $\mathrm{H} 5 \mathrm{~A}, \mathrm{H} 5 \mathrm{~B}$ (strategic management type), which are described below. Hypotheses H1A, H2A, H3A, H4A, and H5A relate to enterprise size and hypotheses H1B, H2B, H3B, H4B, H5B focus on the sector characteristics of enterprises.

\begin{tabular}{|c|c|c|c|c|}
\hline \multicolumn{2}{|c|}{ Relationships Level } & \multicolumn{3}{c|}{ Network Level } \\
\hline Continuity & \multicolumn{2}{c|}{ Complexity } & $\begin{array}{c}\text { Number of } \\
\text { Suppliers }\end{array}$ & $\begin{array}{c}\text { Participation } \\
\text { in Networks }\end{array}$ \\
\hline Length of Cooperation & $\begin{array}{c}\text { Role in } \\
\text { Networks }\end{array}$ & $\begin{array}{c}\text { Management } \\
\text { Type }\end{array}$ \\
\hline Number of Employees & Enterprise Level \\
\hline
\end{tabular}

Figure 1. The model of the research

Source: Processed literature sources.

\section{The characteristics of relationship continuity}

The first research question focuses on the length of business cooperation in buyer-supplier networks and how long agreements and partnerships in networks last. This question relates to the quality of relations, as long-term collaboration is usually the result of a good partnership between enterprises.

Today, there are efforts to create fixed relations with long-time cooperation, based on partnership and mutual exchange of information, which accelerates material flow and creates value-added. The strategic management for cooperation in the network is focused on optimizing the entire value 
chain. Relationships in networks are more complex and long lasting, and their current structure is the result of previous interactions between enterprises (Håkansson \& Ford, 2002). Borgatti and Li (2009) describe the dimensions of relationships in duration, interaction, flow, association, frequency, or power. Long-term arrangements allow enterprises to gain or maintain a competitive advantage and they are considered strategic networks (Jarillo, 1988). Manufacturing enterprises usually choose their leading suppliers for a long period, during which formal or any other types of partnerships could arise. When selecting a new supplier, the enterprise always chooses from several candidates. As a rule, the price of materials, parts, and many other indicators such as quality, speed of delivery, reliability, and other criteria are evaluated (Pech \& Vanecek, 2020). Therefore, enterprises develop relations with suppliers, and with the help of management, they seek to increase the benefits of such cooperation. Unfortunately, most enterprises resist the information exchange because of its possible misuse by competitors. Some of them even prefer informal long-term relationships based on repeated interaction under price-only contracts (Sun \& Debo, 2014).

For this reason, these days, the real partnership comes into existence mostly in industrial production between the assembly plant and suppliers of components, who deliver and transport to the assembly plant the prevailing parts required for production and depend on the assembly plant as a focal enterprise. On the other side, it guarantees them long-time cooperation, passes them the necessary knowledge, and provides them with other advantages. We assume that enterprises in different industry sectors have arranged contracts with their partners for different time intervals. The length of these contracts also varies according to the size of the enterprises. Based on the prevailing opinion on the importance of long-term cooperation of companies in networks, we formulated the following hypotheses:

H1A: There is a relationship between the enterprises' size and the length of cooperation in buyer-supplier networks.

H1B: There is a relationship between the enterprises' sector of industry characteristics and the length of cooperation in buyer-supplier networks.

\section{The characteristics of network complexity}

The second research question comprises the essential buyer-supplier network characteristics related to the complexity of connections between enterprises. We asked managers how many relationships with suppliers and how many links to supply chain networks they maintained. 
The concept of network complexity is not entirely new. Simon (1972) stated that buyer-supplier relationships formed a complex network consisting of many buyers and suppliers embedded in each other. According to Govindan, Fattahi, and Keyvanshokooh (2017), classic buyer-supplier and supply chain concepts provide a too simple view, so current authors favor the term supply chain network current market uncertainty. Christopher (2016) recommends replacing the term chain with the term web or network, because there are many suppliers and their suppliers, similarly as there are customers and their customers. This area's interest has led to a viable approach that the organization works with many - often hundreds - of different products, each of which has its supply chain. Supply chains are no longer a linear representation of independent entities. The term network, which includes many interconnected enterprises in a given transaction, is increasingly emphasized. According to Lambert and Cooper (2000, p. 1), "the supply chain is not a chain of businesses with one-to-one business-to-business relationships, but a network of multiple businesses and relationships." According to Bozarth, Warsing, Flynn, and Flynn (2009), supply chains are dynamic and complex systems with unstable and unpredictable behaviors (Roelich et al., 2015).

Many studies of network complexity in supply chains focus on innovation (Bellamy, Ghosh, \& Hora, 2014), performance (Lu \& Shang, 2017), environment (Adhikary, Sharma, Diatha, \& Jayaram, 2020), disruptions (Bode \& Wagner, 2015) and other topics. Networks are often analyzed by game theory, network and relationship structure models, models of network dynamics, strategic network models, monopoly, and oligopoly models. The complexity is often measured by entropy (Wen \& Jiang, 2019) or similar complexity indicators (Modrak \& Bednar, 2016).

Many studies explored different dimensions of complexity. The network's complexity is related to structural (i.e., the total number of elements) and relational (i.e., the total number of relationships) characteristics.

The total number of direct suppliers represents horizontal complexity (Bode \& Wagner, 2015). The supply chain complexity of most organizations has grown incredibly. It is not uncommon for global brands to own tens of thousands or even hundreds of thousands of suppliers (Walmart, companies in the energy industry, etc.). The real-world situation is mostly unknown. Most enterprises only estimate the size of their supply base. Other dimensions include the number of the next (higher) tier suppliers or their geographical dispersion (Lu \& Shang, 2017). Structural and operational complexity is distinguished by Cheng, Chen, and Chen (2014) to differentiate static and dynamic network variables. 
A supply chain network is hierarchical and as proposed by Wei, Wang, and Chen (2015) could be represented in two ways: a supply chain system with multiple suppliers (" $N$ " type) and a supply chain system with multiple retailers (" $V$ " type). The type " $N$ " is typical for the automotive industry. The structure is based on the forward chain used to purchase materials, assemble them in manufacturers' factories, and deliver the product to customers (Özceylan, Demirel, Çetinkaya, \& Demirel, 2017). There are many suppliers participating in developing and producing a small number of products. To the contrary, in the agri-food industry a structure of type " $V$ " means that a few suppliers (farms, farmers) supply harvested fruit, vegetables and other commodities for processing in food factories, which produce many different end products. Retailers in the food supply chain are selling thousands of different products, each of which has its own supply chain with a different structure (Zhong, Wang, \& Xu, 2017). This brings higher complexity to the network structure.

Based on related works, we examined the first part of the complexity in buyer-supplier networks as the total number of (tier 1) enterprises' suppliers. We established two hypotheses about the complexity of buyersupplier networks related to the number of suppliers for our research:

H2A: There is a relationship between the enterprises' size and the number of suppliers that enterprises have.

H2B: There is a relationship between the enterprises' sector of industry characteristics and the number of suppliers that enterprises have.

However, the network structure consists of nodes representing autonomous business units such as enterprises that collaborate in relationships. A bunch of relationships connects these enterprises to create products or services. The network's relational complexity means exchange relationships and the contract between enterprises (Hearnshaw \& Wilson, 2013). The network building blocks vary according to the level of analysis at which the research is performed. Most authors referred to networks globally or as a result of mutual interaction between any of the two enterprises called "dyads" (Ashnai, Smirnova, Henneberg, \& Naudé, 2019). Enterprises establish these dyadic arrangements of strategic alliances, joint ventures, supplier networks, or research consortia to cope with current environment changes (Tikkanen \& Halinen, 2003). These relationships' substance is based on different layers: activity links, resource ties, and actor bonds (Håkansson \& Snehota, 1995). Activity links include other technical, administrative, or commercial activities or flows between enterprises. 
Resource ties mean a way how enterprises share and utilize their resources. Actor bonds are characterized as close (strategic) partnerships (or clusters) of enterprises' close collective relationships. The emerging network perspective of supplier relationship management and the relationship between distributors and customers is based on vertical and horizontal relationships. The interconnection types of network elements are, according to Borgatti and Li (2009), similarity (association), relations (joint ventures, alliance, agreement, shares), interactions (competitive or collaborative contracts), and flows (technology, cash, information, material). Although the view of business relations as dyads is prevalent, Håkansson and Ford (2002) pointed out that multiple network effects depend on the third party's relationship. The fundamental building block of a network is not the dyad but the triad (Choi \& Kim, 2008), a fundamental network structure (Wasserman \& Faust, 1995). Choi and Wu (2009) show how dyadic relationships are embedded in the triadic buyer-supplier-supplier relationship.

From the above, it is clear that networks have a very complex relational structure. The second part of the complexity in buyer-supplier networks can therefore be expressed directly via connections engagement in various supply chain networks. We suggest that these enterprise characteristics vary by industry characteristics and enterprise size. Given the above, we established two hypotheses about the complexity of buyer-supplier networks for our research:

H3A: There is a relationship between the enterprises' size and their participation in supply chain networks.

H3B: There is a relationship between the enterprises' sector of industry characteristics and their participation in supply chain networks.

\section{The characteristics of strategic management of networks}

The third research question relates to the strategic management of supply chain networks. We found out how an enterprise can control a network and the roles of enterprises in the network.

To make a complex network more manageable, it seems appropriate to distinguish between various enterprise management roles in the network. The network structure consists of organizers (key/focal enterprises), bridges (enterprises connecting isolated parts of the network), and other network members. They play different roles, powers, and competencies in networks (Gibbons, 2007). Lambert and Cooper (2000) stated that in a network there are two groups of enterprises: primary and supporting members. Another 
distinction is the one between demand-related positions - relating to links to buyers - and supply-related positions - relating to links to suppliers. Wynstra (1994) emphasized the distinction between an enterprise's micro and macro position in relationships. A network's role depends on the interdependence between position dimensions, a firm's demand-related and supply-related positions, and the direct and indirect positions. The enterprise's role in the network is closely related to network strategies.

A supply chain, network leader has the power and competency to manage decisions in a centralized strategy. In supply chain networks, the assembly plant usually becomes a focal enterprise. The focal enterprises influence the supply chain network and information, material, and financial supply chain flows (Pražáková \& Pech, 2019). Pibernik and Sucky (2006) differentiate the focal enterprise's power between monocentric or polycentric supply chains. Managed supply chain networks usually have their control tower, a key (focal, head) enterprise that monitors and manages relationships within networks according to plans (Christopher, 2016). These focal enterprises play a leading role, implementing strategies towards supply chain members (Jia, Gong, \& Brown, 2018). In many vertical networks, the focal enterprise remains in the integrator role and coordinates the network as a hub (Achrol \& Kotler, 1999). The focal enterprise systematically coordinates strategic, traditional business functions and tactics to improve the whole long-term performance (Mentzer, DeWitt, Keebler, Min, Nix, Smith, \& Zacharia, 2001). Jarilo (1988) describes a focal enterprise's role in strategic networks as exclusive relationships with the other network members. According to Chen, Lin, and Yih (2007), a key player in a supply chain is the member who overlooks and leads others, creating an environment in which the partnership with suppliers can grow accordingly. Similarly, Handfield and Nichols (1999) emphasize focal enterprises' governance roles, especially in communication with customers and product or service design. The focal enterprises can control the movement of knowledge flows to distribute asymmetric knowledge sourcing and sharing in internal or external business networks (Scott-Kennel \& Saittakari, 2020). Gulati, Nohria, and Zaheer (2000) proposed that structural holes in a customer-supplier network can be entrusted by power through control and, ultimately, profitability.

Because there are different ways of managing the network, we state that these network members' roles (key or dependent) will differ according to industry characteristics and enterprise size. In the questionnaire survey, we asked enterprise managers whether the enterprise is considered a focal or subsidiary member in the supply chain network. Based on these views, we formulated these hypotheses: 
H4A: There is a relationship between the enterprises' size and their role in managing the supply chain network.

H4B: There is a relationship between the enterprises' sector of industry characteristics and their role in managing the supply chain network.

Heydari, Zaabi-Ahmadi, and Choi (2018) distinguish between centralized and decentralized strategies. The centralized management strategy is related to a focal enterprise role. The alternative decentralized strategy emphasizes a collaborative supply chain management (Danese, 2011). In response to the external environment, enterprises create effective supply chain networks where each member specializes in activities (parts, components, and services) with strong core competencies (Moller \& Halinen, 1999). Enterprises in supply chain networks "cooperate in control, management, and improving the flow of materials and information from the supplier to the end consumer" (Christopher, 2016, p. 4). The essence of this cooperation is the sufficient resolution of conflicts between individual members of this network. Each unit tries to minimize its own cost locally, not the supply chain's total costs (Jung \& Jeong, 2005). In this case, the network's core is a strategic network, a group of enterprises, or a strategic cluster in the supply chain. These enterprises usually create competence groups (Rudberg \& Martin West, 2008). Decentralized strategies require a fully integrated supply chain. This strategy includes integration at the level of information sharing among partners (Shin, 2007). Fawcett (2002) stated that a fully integrated supply chain reality also exists. Still, it tends to be quite rare because only a few enterprises have closed the gaps among the various internal functions. From this fixed integration, today a switchover to virtual integration, enterprises perform their main competencies, and the other activities are relocated to sustainable outsourcing (De Felice, Petrillo, \& Autorino, 2015). The virtual enterprise focuses on strategic planning knowledge and IT management to achieve agility (Clarke, 1998). A special type of managing a supply chain via outsourcing to service providers (external enterprises) is a concept called fourth-party logistics (Hingley, Lindgreen, Grant, \& Kane, 2011).

All strategic choices at the network level need to be aligned with strategic interests, negotiation, and consensus building between partners. The structural logic of strategies is focused on their position (Burt, 2004), the configuration of alliances (lurkov \& Benito, 2018) or supply chains, or relations in the network (Parker \& Cox, 2013). Czakon (2016) categorized them into structural, resource-based, and value-creation types. The resource-based view includes resources (Gulati, Nohria, \& Zaheer, 2000) or competencerelated networks. Value creation means cooperation and ecosystem strategies 
focusing on the environment and sectors providing value to customers. The enterprises in alliances cooperate, but they can even compete in certain areas. This phenomenon is referred to as co-opetition, i.e., cooperation and competition at the same time (Nalebuff \& Brandenburger, 1997). At present, it is no longer just the enterprises that compete, but the entire supply chain network (Gomes-Casseres, 1996).

Based on theory, we distinguish three types of management in supply chain networks: focal enterprise, multiple managing enterprise, and virtual organization management. We expect that these types of management will differ according to industry characteristics and enterprise size. Then, we formulated the last two hypotheses:

H5A: There is a relationship between the enterprises' size and their type of supply chain management.

H5B: There is a relationship between enterprises' sector of industry characteristics and their type of supply chain management.

\section{METHODOLOGY}

This paper explores relationship between enterprise characteristics and some characteristics of buyer-supplier networks from a strategic management and network perspective point of view. We are specifically interested in the aspects of primary networks' tendencies as they pertain according to different sectors of industry and enterprise size. The subject of our research was buyer-supplier relationships, which are part of the supply chain networks. Our objective is to answer research questions related to the importance of enterprise characteristics for network features such as complexity, continuity of relationships, and networks' strategic management.

The quantitative empirical research is based on the structured questionnaire survey administered by the research team from October 2016 till February 2018. We realized additional research in 2019 for a deeper analysis of supply chain, management types. We obtained primary data from a questionnaire survey of 360 enterprises engaged in supply chains. The research was conducted on enterprises doing business in the Czech Republic; however, $44 \%$ of them have ownership ties with other European countries. The research sample size was determined based on the number of 416,351 enterprises (population sample) in the Czech Republic (Czech Statistical Office, 2019) in the industry's observed sectors in 2018. We used the non-probability purposive sampling method for choosing enterprises. According to the sample size and population sample, the 
estimated margin of error approximation at a 95\% confidence level is about $5.17 \%$. Therefore, the research data are representative concerning the entire population of enterprises.

The structured questionnaire contains questions related to some buyer-supplier network characteristics. The items in the questionnaire were pre-tested for validity by 15 managers using the Delphi method. The feedback helped to set the appropriate nominal scales in the questionnaire. The questions in the survey focus on four main areas: number of suppliers (categories 1-10, 11-50, 51-100, 101, and more), engagement in supply chain networks (categories: 1-5, 6-20, 21 and more), management of networks (key or dependent role in supply chain network), and duration of cooperation between enterprises (short-term collaboration, i.e., less than one year; longterm partnership, i.e., over one year; different contract periods). Additional questionnaire research in 2019 focused on the types of strategic management of networks (categories of supply chain management: one focal enterprise, multiple managing enterprises, special (virtual) organization). Respondents had the option of choosing one of the answers to the closed question. The frequency of respondents' responses to the given topics was thus determined.

The data collected from questionnaires consists of an online survey (questionnaire on webpages) or a personal visit to the enterprise (printed questionnaire), including telephone calls combined with an e-mail invitation to participate in the research. The research team involved representatives of academics and students of the University of South Bohemia in České Budějovice. The group of respondents consisted entirely of managers, mostly from the field of logistics and management. Trained members of the research team helped the managers and CEOs complete the questionnaire, and they also explained any items the respondents wished to clarify. In the online survey, a contact point and a link to a more detailed explanation of any ambiguities in the questionnaire, questions were available. The completed questionnaires were obtained with an overall response rate of $20 \%$ for online data collection and $85 \%$ for personal collecting of questionnaires. Of the 482 completed questionnaires, 11 were eliminated due to incomplete or missing responses. We excluded 111 questionnaires of enterprises without supply chain engagement. The data consist of a total of 360 answers from the questionnaire (Table 1).

We processed the data sample according to the size and sector of enterprises' industry characteristics (Table 1). The classification of enterprises by sector of industry (specialization) is based on the prevailing industry focus. 
Table 1. Research sample

\begin{tabular}{lllll}
\hline \multirow{2}{*}{ Group } & Category of Enterprise & \multicolumn{3}{c}{ Characteristics of Research Sample } \\
\cline { 3 - 5 } & & $\begin{array}{l}\text { Main Research } \\
(\mathbf{2 0 1 6 - 2 0 1 8 )}\end{array}$ & $\begin{array}{l}\text { Additional } \\
\text { Research } \\
(\mathbf{2 0 1 9 )}\end{array}$ & Total (n) \\
\hline \multirow{3}{*}{$\begin{array}{l}\text { Engineering and Electro-technical } \\
\text { production }\end{array}$} & 146 & 35 & \\
industry & Household supplies & 61 & 5 & 360 \\
& Food production & 54 & 8 & \\
& $\begin{array}{l}\text { Chemical, paper and non- } \\
\text { metallic production }\end{array}$ & 20 & 16 & 360 \\
& Agriculture & 15 & 0 & \\
Size & Small Enterprises & 86 & 15 & \\
& Medium-sized Enterprises & 109 & 20 & \\
& Large Enterprises & 101 & 29 & \\
\hline
\end{tabular}

Source: Survey data.

This category defined groups based on the CZ-NACE classification (Czech Statistical Office, 2019) into Engineering and electro-technical production (groups 24-30), Production of products for domestic use (Groups 13-16, 3132; household supply), Food production industry (Groups 10-12), Chemical paper and non-metallic production (groups 17-23), and Agriculture (groups 01-03). The classification of enterprise size is based on European Commission methodology (2003). We analyzed the groups of small enterprises (1049 employees), medium-sized enterprises (50-249 employees), and large enterprises (over 250 employees). More than half of the enterprises related to the engineering (50.28\%) industry in the data sample. About $18.33 \%$ of enterprises consist of enterprises of household goods production, and $17.22 \%$ of food production enterprises. The other fields (chemical, paper and non-metallic production, agriculture) cover about $14.17 \%$. According to their size (number of employees), enterprises' distribution is roughly the same (around $28-36 \%$ for all categories).

The analysis is based on the data from questionnaires. The research is set out to test the five hypotheses ( $\mathrm{H} 1-\mathrm{H} 5)$ for each group of enterprises. The null hypothesis for the hypotheses is that there are no differences between groups of enterprises. It means that their proportion is not different in at least one case. The hypotheses were tested based on enterprise size and then by industry characteristics. To evaluate results, we carried out a statistical analysis using "individual tests of equal and given proportions without correlation to continuity," i.e., two-proportion Z-Test (Field, Miles, \& Field, 2012). We compared the total number of enterprises and the 
total number of observations according to the enterprise size or industry characteristics. The calculation is based on a weighted sum of squared deviations between the observed proportions in each group and the overall proportion. The test statistics are defined as follows:

$$
z=\frac{p_{A}-p_{B}}{\sqrt{p q / n_{A}+p q / n_{B}}}
$$

where,

$p_{\mathrm{A}}$ is the proportion observed in the group A with size $n_{\mathrm{A}}$ $p_{\mathrm{B}}$ is the proportion observed in the group B with size $n_{\mathrm{B}}$ $p$ and $q$ are the overall proportions

The analysis of the data was performed in the $\mathrm{R} 3.6$ programming environment. The statistical significance level of differences was set at 0.05 . Significant results (including the achieved level of significance - p-value) are presented in the text. In case of significant differences between proportions in the observed groups, a pairwise comparison test with the Holm method adjustment (Holm, 1979) is used.

\section{RESULTS AND DISCUSSION}

According to the working hypotheses, this analysis summarized three main areas: length of cooperation between enterprises, network complexity, and strategic management of networks. Based on the survey data, we investigated whether enterprises differ based on their size and sector of industry characteristics.

\section{The characteristics of relationship continuity}

Using the questionnaires data, we were able to investigate the duration of cooperation between enterprises. Long-term cooperation is essential for easier strategic planning and relationship management. In terms of industry classification, enterprises with short-term supplier relationships predominate. An interesting finding is that only in the food sector are contracts concluded for various periods. According to enterprise size, small enterprises mainly prefer short-term contracts. On the contrary, medium-sized and large enterprises enter into agreements for multiple periods (Table 2). 
Table 2. Length of Cooperation between Enterprises in 2016-2018 (in \%, $\mathrm{n}=230$ )

\begin{tabular}{|c|c|c|c|c|}
\hline \multirow[b]{2}{*}{ Group } & \multirow[b]{2}{*}{ Category of Enterprise } & \multicolumn{3}{|c|}{$\begin{array}{c}\text { Length of Cooperation between } \\
\text { Enterprises }\end{array}$} \\
\hline & & $\begin{array}{l}\text { Short-term } \\
\text { cooperation } \\
\text { (<1 year) }\end{array}$ & $\begin{array}{l}\text { Long-term } \\
\text { cooperation } \\
\text { (>1 year) }\end{array}$ & $\begin{array}{l}\text { Different } \\
\text { Contract } \\
\text { Periods }\end{array}$ \\
\hline \multirow{5}{*}{$\begin{array}{l}\text { Sector } \\
\text { of } \\
\text { industry }\end{array}$} & $\begin{array}{l}\text { Engineering and Electro-technical } \\
\text { production }\end{array}$ & 44.95 & 11.01 & 44.04 \\
\hline & Household supplies & 43.48 & 13.04 & 43.48 \\
\hline & Food production & 39.47 & 23.68 & 36.84 \\
\hline & $\begin{array}{l}\text { Chemical, paper and non-metallic } \\
\text { production }\end{array}$ & 30.00 & 35.00 & 35.00 \\
\hline & Agriculture & 58.82 & 11.76 & 29.41 \\
\hline \multirow{3}{*}{ Size } & Small Enteprises & 62.86 & 8.57 & 28.57 \\
\hline & Medium-sized Enterprises & 41.86 & 13.95 & 44.19 \\
\hline & Large Enterprises & 27.03 & 25.68 & 47.30 \\
\hline
\end{tabular}

Source: Survey data processed.

The evaluation of hypotheses $\mathrm{H} 1 \mathrm{~A}$ and $\mathrm{H} 1 \mathrm{~B}$ is shown in Table 3. Hypothesis H1A states: "There is a relationship between the enterprises' size and the length of cooperation in buyer-supplier networks". The hypothesis H1A (by enterprise size) is accepted. It was found that enterprise size is predominant in the length of cooperation between enterprises for all categories (shortterm $p$-value $=0.0000$, long- term period $p$-value $=0.0161$, different contract time $p$-value $=0.0488$ ). Therefore, we state that an enterprise's size affects how long it has been working with other enterprises. The difference in duration of cooperation among enterprises of different sizes is significant. Hypothesis H1B states: "There is a relationship between the enterprises' sector of industry characteristics and the length of cooperation in buyersupplier networks." The hypothesis H1B (by sector of industry) is rejected. There were no differences between sectors of industry in terms of the length of cooperation between enterprises. The industry sector is not the main factor that influences the duration of collaboration between enterprises. 
Table 3. Length of Cooperation between Enterprises in 2016-2018 $(n=230)$

\begin{tabular}{|c|c|c|c|c|}
\hline \multirow[t]{2}{*}{ Length of Cooperation } & \multicolumn{2}{|c|}{ H1A: Size differences } & \multicolumn{2}{|c|}{$\begin{array}{l}\text { H1B: The sector of } \\
\text { industry differences }\end{array}$} \\
\hline & Z-score & p-value & Z-score & p-value \\
\hline $\begin{array}{l}\text { Short-term cooperation } \\
\text { (less than } 1 \text { year) }\end{array}$ & 18.9380 & $0.0000^{*}$ & 3.4520 & 0.4852 \\
\hline $\begin{array}{l}\text { Long-term cooperation } \\
\text { (over } 1 \text { year) }\end{array}$ & 8.2592 & $0.0161^{*}$ & 9.3585 & 0.0527 \\
\hline Different contract periods & 6.0398 & $0.0488^{*}$ & 3.2302 & 0.5201 \\
\hline
\end{tabular}

Overall, only the size of enterprises influenced the length of cooperation between enterprises. While small enterprises tend to use short-term contacts, large enterprises encourage long-term relationships. However, for large enterprises, our research has confirmed the use of contracts of different periods. This finding may indicate the selection and careful choice of partners for long-term relationships. The most successful manufacturers seem to have carefully linked their internal processes to external suppliers and customers in unique supply chains. In the new millennium, upstream and downstream integration with suppliers and customers has emerged as a vital manufacturing strategy element (Frohlich \& Westbrook, 2001). This type of interconnection is only possible in the case of long-term cooperation between enterprises. A special kind of partnership between supplier-purchaser is described in the literature, connected with Japanese-style management as a vertical "keiretsu" (Yamada, 2019). A Japanese vertical partnership includes classic long-term contractual arrangements between enterprises and mutual assistance, willingness to make significant customized investments, intensive and regular sharing of information, and trust-building practices. From the strategic management perspective, enterprises should foster and develop their relationships with partners for a longer period.

\section{The characteristics of network complexity}

The first factor examined to determine the complexity of the network was the number of suppliers. It is interesting to note that the highest number of enterprises has 11-50 suppliers (Table 4), but it was more than one hundred in some cases. This quantity depends on the production's character, and it is not possible to recommend decreasing their number, not even in situations when two or more suppliers deliver the same items. 
Table 4. Number of Suppliers for Enterprises in 2016-2018 (in \%, $n=232$ )

\begin{tabular}{llrlll}
\hline \multirow{2}{*}{ Group } & Category of Enterprise & \multicolumn{4}{c}{ Number of Suppliers for Enterprises } \\
\cline { 3 - 6 } & & $\mathbf{1 - 1 0}$ & $\mathbf{1 1 - 5 0}$ & $\mathbf{5 1 - 1 0 0}$ & $\mathbf{1 0 1}$ and more \\
\hline \multirow{2}{*}{$\begin{array}{l}\text { Engineering and Electro-technical } \\
\text { production }\end{array}$} & 18.35 & 44.04 & 11.93 & 25.69 \\
Sector & Household supplies & & & & \\
of & Food production & 27.66 & 40.43 & 21.28 & 10.64 \\
& industry & 25.64 & 48.72 & 12.82 & 12.82 \\
& Chemical, paper and non-metallic & 10.00 & 55.00 & 10.00 & 25.00 \\
& production & & & & \\
& Agriculture & 41.18 & 41.18 & 11.76 & 5.88 \\
\hline \multirow{3}{*}{ Size } & Small Enteprises & 45.71 & 47.14 & 4.29 & 2.86 \\
& Medium-sized Enterprises & 18.60 & 54.65 & 16.28 & 10.47 \\
& Large Enterprises & 5.26 & 31.58 & 19.74 & 43.42 \\
\hline
\end{tabular}

Source: Survey data processed.

The most significant number of suppliers was found in large and medium-sized enterprises. A larger number of suppliers bring advantages in their possible competition, possibilities of differentiation, and distribution of risks. Potential problems occur later when the supplier does not fulfill his contracted duties. With increasing tension and supply chain interdependence, a failure in any link can lead to a production shutdown (Berger, Gerstenfeld, \& Zeng, 2004). However, fewer suppliers mean easier control, management, and integration into the supply chain network. It may be essential for some companies to determine the optimal number of suppliers to eliminate the risk of failure. Unique models allow simulating decision-making processing to consider the optimal level and the number of suppliers according to the probability of avoiding risks (Ruiz-Torres \& Mahmoodi, 2007).

The evaluation of hypothesis $\mathrm{H} 2 \mathrm{~A}$ and $\mathrm{H} 2 \mathrm{~B}$ continues in Table 5 . The second part of the complexity hypotheses H2A states: "There is a relationship between the enterprises' size and the number of suppliers that enterprises' have." The hypothesis $\mathrm{H} 2 \mathrm{~A}$ (by enterprise size) is accepted. The working hypothesis was proved for the size classification in all the researched categories (1-10 $p$-value $=0.0000^{*}, 11-50 \mathrm{p}$-value $=0.0117^{*}, 51-100 \mathrm{p}$-value $=0.0181^{*}, 101$ and more $\mathrm{p}$-value $\left.=0.0000^{*}\right)$. Thus, it can be stated that the size of an enterprise affects how many suppliers an enterprise has. The hypothesis H2B states: "There is a relationship between the enterprises' sector of industry characteristics and the number of suppliers that enterprises' have." The hypothesis H2B (by sector of industry) is rejected. There were no statistically significant differences in the number of suppliers among enterprises. 
Table 5. Number of Suppliers for Enterprises 2016-2018 ( $n=232$ )

\begin{tabular}{lrlll}
\hline \multirow{2}{*}{ Number of suppliers } & \multicolumn{2}{c}{ H2A: Size differences } & \multicolumn{2}{c}{$\begin{array}{r}\text { H2B: The sector of } \\
\text { industry differences }\end{array}$} \\
\cline { 2 - 5 } & Z-score & p-value & Z-score & p-value \\
\hline 1-10 suppliers & 35.4260 & $0.0000^{*}$ & 7.2269 & 0.1244 \\
11-50 suppliers & 8.9010 & $0.0117^{*}$ & 1.5629 & 0.8154 \\
51-100 suppliers & 8.0263 & $0.0181^{*}$ & 2.8648 & 0.5807 \\
101 and more suppliers & 45.4380 & $0.0000^{*}$ & 8.6514 & 0.0704 \\
\hline
\end{tabular}

Source: Survey data processed.

Secondly, we examined results concerning the number of supply chain networks in which enterprises are involved. An overall summary of the results is given in Table 6. Most enterprises are involved in multiple networks. In line with the findings, we report that the first two categories (1-5 and 6-20) prevail. The type with 1-5 supply chain, network engagement predominates for household goods enterprises. Enterprises in the food and engineering industry are mostly involved in 6-20 supply chain networks. Interestingly, agriculture enterprises are mainly engaged in fewer (category 1-5) supply chain networks.

We did the subsequent analysis to find out whether the size of the enterprises showed significant differences. Small and medium-sized enterprises are involved only in a small number of supply chain networks (1-5). Large enterprises are substantially involved in 21 or more networks. These results are in agreement with our expectations. This finding can be explained by the regional factors, where small businesses are targeting a smaller region, and large enterprises operate more internationally in multiple supply chain networks. We think that this discrepancy is because these large enterprises plan their activities efficiently in chains, especially in delivering a specific amount of materials and deadlines. 
Table 6. Number of Supply Chains in which were Enterprises engaged in 2016-2018 (in \%, $\mathrm{n}=178$ )

\begin{tabular}{lllll}
\hline \multirow{2}{*}{ Group } & Category of Enterprise & \multicolumn{3}{c}{$\begin{array}{c}\text { Number of Supply Chain } \\
\text { Networks }\end{array}$} \\
\cline { 3 - 5 } & $\begin{array}{l}\text { Engineering and Electro-technical } \\
\text { production }\end{array}$ & $\mathbf{1 - 5}$ & $\mathbf{6 - 2 0}$ & $\mathbf{2 1}$ and more \\
\hline \multirow{3}{*}{$\begin{array}{l}\text { Sector of } \\
\text { industry }\end{array}$} & Household supplies & 40.86 & 25.81 \\
\cline { 2 - 5 } & Food production & 61.54 & 25.64 & 12.82 \\
\cline { 2 - 5 } & Agriculture & 33.33 & 43.33 & 23.33 \\
\hline \multirow{3}{*}{ Size } & Small Enteprises & 68.75 & 18.75 & 12.50 \\
\cline { 2 - 5 } & Medium-sized Enterprises & 60.34 & 34.48 & 5.17 \\
\cline { 2 - 5 } & Large Enterprises & 46.97 & 39.39 & 13.64 \\
\hline Source: Survey data processed. & 18.52 & 33.33 & 48.15 \\
\hline
\end{tabular}

The results of the evaluation of hypothesis $\mathrm{H} 3 \mathrm{~A}$ and $\mathrm{H} 3 \mathrm{~B}$ are presented in Table 7. Hypothesis H3A states: "There is a relationship between the enterprises' size and their participation in supply chain networks." The hypothesis H3A (by enterprise size) is accepted. In terms of size, the differences among enterprises are statistically significant at the significance level of $5 \%$ for all categories (for 1-5 supply chain networks $p$-value $=0.0000$, for 21 and more supply chain networks $p$-value $=0.00000$ ) except category $6-20$ supply chain networks. It is interesting to note that the size of the enterprise affects its involvement in supply chain networks. Hypothesis H3B states: "There is a relationship between the enterprises' sector of industry characteristics and their participation in supply chain networks." The hypothesis H3B (by sector of industry) is rejected. The only significant difference was confirmed in category 1-5 supply chain networks ( $p$-value $\left.=0.0023^{*}\right)$. In other cases, the differences are not approved. Therefore, we conclude that the sector of the industry is not relevant to the involvement in supply chain networks. 
Table 7. Number of Supply Chain Networks in which were Enterprises engaged in 2016-2018 $(n=178)$

\begin{tabular}{|c|c|c|c|c|}
\hline \multirow{2}{*}{$\begin{array}{l}\text { Number of supply chain } \\
\text { networks engagements }\end{array}$} & \multicolumn{2}{|c|}{ H3A: Size differences } & \multicolumn{2}{|c|}{$\begin{array}{l}\text { H3B: The sector of } \\
\text { industry differences }\end{array}$} \\
\hline & Z-score & p-value & Z-score & p-value \\
\hline $\begin{array}{l}\text { Engagement in 1-5 supply } \\
\text { chain networks }\end{array}$ & 20.7780 & $0.0000^{*}$ & 14.5050 & $0.0023^{*}$ \\
\hline $\begin{array}{l}\text { Engagement in 6-20 supply } \\
\text { chain networks }\end{array}$ & 0.5577 & 0.7578 & 5.5394 & 0.1363 \\
\hline $\begin{array}{l}\text { Engagement in } 21 \text { and more } \\
\text { supply chain networks }\end{array}$ & 34.4750 & $0.0000^{*}$ & 3.6064 & 0.3072 \\
\hline
\end{tabular}

The network's overall complexity is shown in Figure 2, where the two factors' frequencies are expressed concerning each other. The coordinates of the points are based on a random representation of both factors' values in given intervals. Although it is not possible to express the relationship's dependence by an exact correlation coefficient, a certain tendency can be traced from Figure 2 (if we omit outliers).

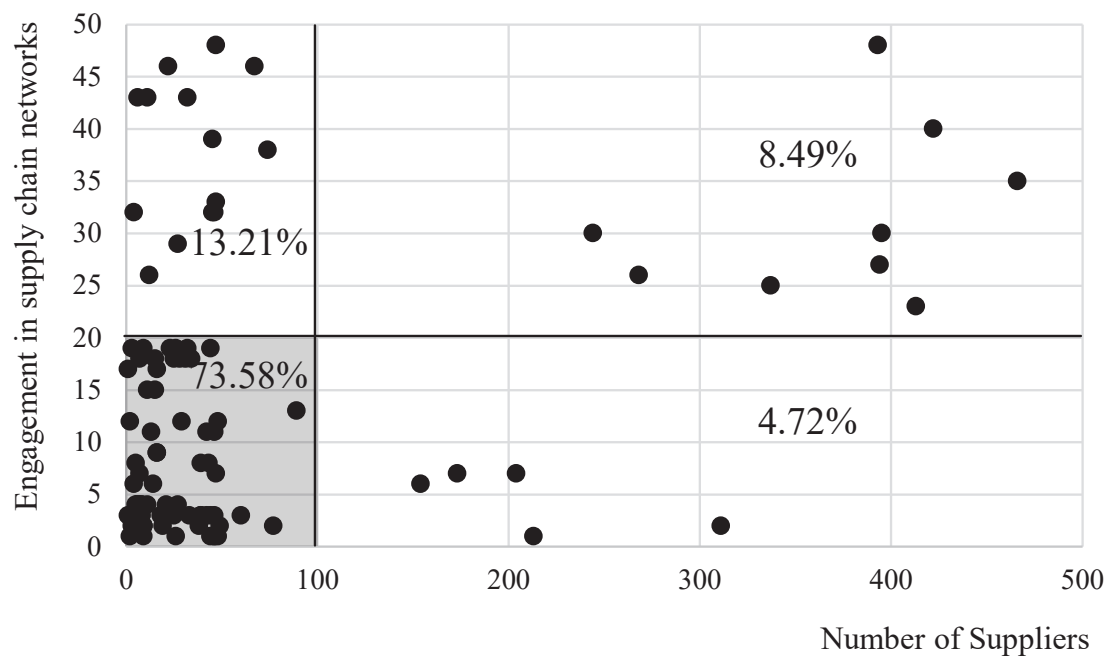

Figure 2. Number of Suppliers concerning Engagement in Supply Chain Networks $(n=230)$

Source: Survey data, processed. 
Enterprises with a larger number of suppliers and a higher involvement in supply networks are rare. Most enterprises have less than 100 suppliers and are involved in less than 20 supply chain networks (73.58\%). This situation is described as a power-law distribution in scale-free networks (Guo, 2006). Thus, there may be so-called authorities with many suppliers or hubs that connect key links in the supply chain network.

To summarize the results of hypothesis $\mathrm{H} 2$ and $\mathrm{H} 3$, we found that the industry sector is not relevant to the involvement in supply chain networks and the number of suppliers. The more substantial variable that affects the number of engagements and suppliers is the size of the enterprise. From a network complexity perspective, it is relevant that large enterprises are usually involved in multiple supply chain networks. In contrast, small and medium-sized enterprises tend to be engaged in fewer supply chain networks. We found that these enterprises instead tend to maintain relationships with a smaller number of suppliers as well. Many suppliers have mostly large and medium-sized enterprises. A high number of suppliers indicate a rather vast net than traditional supply chains. Communication and management pass only between two neighboring links up and downstream the chain, but not to more distant links from the focal enterprise. When enterprises are involved in hundreds of supply chain networks, this leads to an innate complexity that makes the whole supply chain invisible to management (Yli-Huumo et al., 2016). A comparison with the number of supplier frequencies in Smolová's (2008) research shows similar tendencies. Although, today, there is a prevailing view of networks' high complexity, the global trend in suppliercustomer relationships is probably to reduce the number of suppliers. This finding brings a particular risk of late deliveries, especially when deliveries are from other continents. In such cases, only a supplier of essential components would represent a considerable risk for the enterprise. From the strategic management perspective, supply chain management is primarily focusing on a key group of suppliers and developing relationships with them.

\section{The characteristics of strategic management of networks}

The strategic management of networks area was divided into two parts: the role in the supply chain network (key or dependent) and the type of supply chain management (management by focal enterprise, multiple managing enterprises, or virtual enterprise).

First, we explored the role of enterprises in supply chain networks. According to Figure 3, enterprises, in the majority of cases, are unlikely to play a key role in supply chain networks. However, many enterprises from the agriculture industry are only in a dependent position. This situation is 
usually not mentioned in the literature. It is suspected that this may be due to the strategy of differentiation. Another strategy should be formulated for goods in supply chains. The enterprise plays a focal enterprise and another role when it is only in a dependent position.

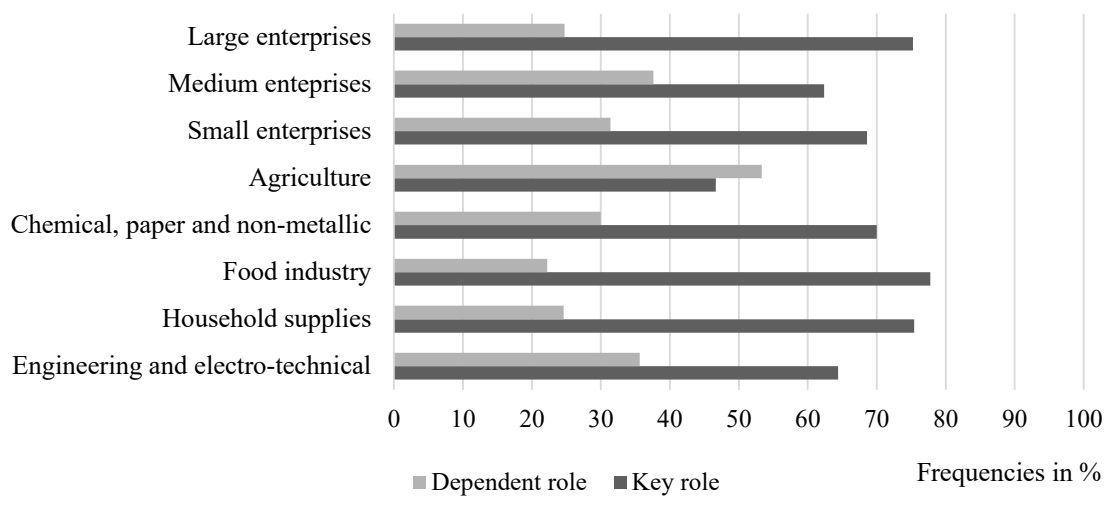

Figure 3. Enterprise' Role in Supply Chain Network

Source: Survey data, processed $(n=296)$.

The evaluation of hypotheses H4A and H4B is shown in Table 8, based on the comparison of key and dependent roles of the enterprises in supply chain. Hypothesis H4A states: "There is a relationship between the enterprises' size and their role in managing the supply chain network." The hypothesis H4A (by enterprise size) is rejected. The significant differences in supply chain, network roles were not confirmed according to the enterprise size. The hypothesis H4B states: "There is a relationship between the enterprises' sector of industry characteristics and their role in managing the supply chain network." The hypothesis H4B (by sector of industry) is rejected. The significant differences in supply chain, network roles were not confirmed according to the sector of industry.

The focal enterprise in a key position should manage the whole supply chain network or at least to drive its closest neighbors. That means to set the necessary volumes of materials, their delivery terms, and acceptable prices. As focal enterprises are pushing to decrease costs, they help to search for reserves and remove unnecessary activities. Large enterprises play a key role more often. 
Table 8. Supply Chain Management Role in 2016-2018 ( $n=296)$

\begin{tabular}{lllll}
\hline \multirow{2}{*}{\begin{tabular}{l} 
Supply chain management \\
\cline { 2 - 5 }
\end{tabular}} & \multicolumn{2}{c}{$\begin{array}{c}\text { H4A: Size } \\
\text { differences }\end{array}$} & $\begin{array}{c}\text { H4B: The sector } \\
\text { of industry } \\
\text { differences }\end{array}$ \\
\cline { 2 - 6 } & Z-score & p-value & Z-score & p-value \\
\hline Key vs. Dependent Role in Supply Chain & 4.025 & 0.1337 & 7.9954 & 0.0918 \\
\hline
\end{tabular}

Source: Survey data processed.

Small and medium-sized enterprises are rarely in key positions since they experience issues regarding the alignment of the supply chain strategies and a low level of influence (Calderon, Roark, Urrutia, Paravie, \& Rohvein, 2017). At the contemporary time, enterprises are aware of their position and role in the supply chain network.

Furthermore, we applied a deeper analysis of supply chain, management types based on the additional research in 2019. This research sample contained only 64 enterprises. An outstanding question related to supply chain network management discusses supply chain managers' work in more detail. We asked managers whether only one or more enterprises manage the supply chain. Managing through multiple enterprises (key links) is possible for longer supply chains. For example, one focal enterprise manages businesses' activities in the European country and activities in Asia. In this example, the necessary parts are supplied and transported to different factories in different countries. The questionnaires' results appeared totally in line with our expectations that the supply chain is driven by several key links, more often in longer supply chains (Table 9). Enterprises in the food industry, the household sector, and large and medium-sized enterprises play a key role in the network. However, more enterprises are involved in the management of the whole network. 
Table 9. Supply Chain Management in 2019 (in \%, n = 64)

\begin{tabular}{|c|c|c|c|c|}
\hline \multirow[b]{2}{*}{ Group } & \multirow[b]{2}{*}{ Category of Enterprise } & \multicolumn{3}{|c|}{ Supply Chain Management } \\
\hline & & $\begin{array}{l}\text { One Focal } \\
\text { Enterprise }\end{array}$ & $\begin{array}{l}\text { Multiple } \\
\text { managing } \\
\text { enterprises }\end{array}$ & $\begin{array}{l}\text { Special } \\
\text { (virtual) } \\
\text { organization }\end{array}$ \\
\hline \multirow{4}{*}{$\begin{array}{l}\text { Sector of } \\
\text { industry }\end{array}$} & $\begin{array}{l}\text { Engineering and Electro-technical } \\
\text { production }\end{array}$ & 28.57 & 57.14 & 14.29 \\
\hline & Household supplies & 20.00 & 80.00 & 0.00 \\
\hline & Food production & 50.00 & 37.50 & 12.50 \\
\hline & $\begin{array}{l}\text { Chemical, paper and non-metallic } \\
\text { production }\end{array}$ & 37.50 & 62.50 & 0.00 \\
\hline \multirow{3}{*}{ Size } & Small Enteprises & 13.33 & 73.33 & 13.33 \\
\hline & Medium-sized Enterprises & 40.00 & 45.00 & 15.00 \\
\hline & Large Enterprises & 37.93 & 58.62 & 3.45 \\
\hline
\end{tabular}

Source: Survey data processed.

The analyzed types of management are focal enterprise (centralization strategy), multiple managing enterprise (decentralization strategy), and special (virtual) organization (part of decentralization strategy). The evaluation of hypotheses H5A and H5B is shown in Table 10. Hypothesis H5A states: "There is a relationship between the enterprises' size and their type of supply chain management." The hypothesis H5A (by enterprise size) is rejected. The significant differences in supply chain, management type were not confirmed according to the enterprise size. The hypothesis H5B states: "There is a relationship between the enterprises' sector of industry characteristics $s$ and their type of supply chain management." The hypothesis H5B (by sector of industry) rejected. The significant differences in supply chain, management type were not confirmed according to the sector of industry.

Table 10. Supply Chain Management in 2019

\begin{tabular}{lllll}
\hline \multirow{2}{*}{ Supply chain management } & \multicolumn{2}{c}{ H5A: Size differences } & \multicolumn{2}{c}{$\begin{array}{c}\text { H5B: The sector of industry } \\
\text { differences }\end{array}$} \\
\cline { 2 - 5 } & Z-score & p-value & Z-score & p-value \\
\hline One key (focal) enterprise & 3.3950 & 0.1831 & 1.8893 & 0.5957 \\
Multiple managing enterprises & 2.8355 & 0.2423 & 2.5131 & 0.4729 \\
Special (virtual) organization & 2.2204 & 0.3295 & 3.2578 & 0.3536 \\
\hline SOunyyyy
\end{tabular}

Source: Survey data processed.

The results show no differences between enterprises according to their size and sector of industry in supply chain, management types of strategy. In the past, long intercontinental supply chains had the advantage of 
supplying inexpensive components for assembly factories. This advantage has gradually disappeared as wages have increased in developing countries and the manufacturing of parts has been transferred back to the mother country. This process is known as the 'globalization to localization' path, the use of local resources. The return to local resources will be possible mainly by applying mass 3D printing and additive manufacturing technologies in parts production. It will not increase employment because fully automated production is expected.

Overall, the different supply chain, management roles or types are not related to industry characteristics' enterprise size or sector. From the strategic management perspective, decentralized kinds of strategies in supply chain networks are used the most. This is an exciting finding, and it could be anticipated that a decentralized strategy is usually related to the cooperation of enterprises on supply chain management. Regardless of the industry's size or sector, it is possible to state there are more uncomfortably managed enterprises in the supply chain with divided competencies. Some enterprises in the network have more confidence and power to control others. However, some authors emphasize the importance of the customer as a crucial element in managing future, supply chain networks. This fundamental change from a production-driven chain to a demand-driven chain is being pushed by market forces and enabled by new technologies (Christopher \& Ryals, 2014). It strengthens all physical processes and information flows, when and where they are needed, across manufacturing supply chain networks, in multiple industries (Wan, Tang, Li, Wang, Liu, Abbas, \& Vasilakos, 2017).

\section{CONCLUSION}

In view of global challenges, the role of strategic management is emphasized in leading complex networks of long-term relationships between enterprises. This paper offers several contributions to supply chain management and attempts to respond to calls for studies that are connecting strategic management concepts with the network perspective. The paper particularly emphasizes the role of complexity, continuity, and strategic management of relationships in contemporary buyer-supplier and supply chain networks.

In conclusion, we have shown some contemporary characteristics of enterprises engaged in buyer-supplier networks. The results of four years of research emphasize that most enterprises are involved in multiple networks. These enterprises prefer to maintain relationships with a small number of suppliers. We found that the complexity of networks in the Czech Republic is not high unless the network is a part of a global supply chain. Overall, the 
main differences between the enterprises involved in the supply chain were in their size. Enterprise size affects the number of supply chain networks in which they are involved, the number of suppliers, and the duration of the relationship with their partners. Hypotheses $\mathrm{H} 1 \mathrm{~A}, \mathrm{H} 2 \mathrm{~A}$ and $\mathrm{H} 3 \mathrm{~A}$ were confirmed and enterprise size is a relevant factor in supply chains. In buyer-supplier relations, there is a higher tendency to maintain long-term relationships with a smaller number of partners, with the goal being the possibility of integration of modern technologies. From the results, we have drawn that the industry sector has no impact on the enterprises involved in supply chain networks.

The strategic management of networks is a current challenge in network research. We analyzed enterprises engaged in supply chain networks to explore their roles in networks and preferred types of management. Results show that hypotheses H4A and H4B cannot be confirmed. Thus enterprise size or industry characteristics are not important for position in key or dependent roles in supply chain networks. We further focused on the types of supply chain management of enterprises. It can be argued that enterprises should apply two different strategies (centralization, decentralization) depending on the products (or parts of products) they are finalizing. Hypotheses $\mathrm{H} 5 \mathrm{~A}$ and $\mathrm{H} 5 \mathrm{~B}$ were not confirmed. From the results, we have drawn that the prevailing strategy is decentralization. Enterprises distribute competencies among several members of the network, regardless of the size of the enterprise or industry. This result finds applications in strategic management and opens new questions from the network approach perspective.

There are some limitations associated with the research. In this research, we examined the complexity of buyer-supplier network relationships based on data (the number of suppliers and their involvement in supply chains). From the network perspective, it is more appropriate to use all business contacts, i.e., without the direction of ties (in the case of supply chains all suppliers and customers). The research procedure used was selected because of its aim in the direction of material flow. The complexity is also measured in some studies using other indicators, such as entropy. We are aware of this shortcoming and plan to remove this limitation in further research. Although we use a single small country, the Czech Republic, as an object to answer our research questions, the research sample contains about $44 \%$ of enterprises with ownership ties to other European countries. The research sample consists of an equal representation of enterprises of all sizes (number of employees). However, we admit that the results of enterprises from the analyzed sectors of an industry may not allow the generalization of the findings to all (mostly global) networks. In addition, the research sample for the evaluation of hypotheses $\mathrm{H} 5 \mathrm{~A}$ and $\mathrm{H} 5 \mathrm{~B}$ is smaller in size and differs 
from the data sample for other hypotheses. We made this additional research and analysis for greater depth of strategic aspects of supply chain networks. Nevertheless, we think that the research results provide exciting conclusions concerning the strategic management of networks.

Several theoretical implications emerge from the research study results. Our study helps advance the theoretical development of strategic management in supply chain network management and accentuates the importance of developing and fostering business collaboration. According to Håkansson \& Snehota (1995) any change in a business relationship has three types of effects: at enterprise level, at the level of interplay among enterprises, and a more indirect reaction in the overall network. We focused on enterprise characteristics that may influence other levels. Our model shows mainly dependences of enterprise size at the business relationship level for business cooperation continuity and partially for network complexity. At the network level were enterprise characteristics viable only for participation in networks. Thus, the strategic management of networks is independent to some characteristics of enterprises. This conclusion supports the idea of an indirect effect at the network level (Håkansson \& Snehota, 1995). We believe that the synthesis of supply chain management and network approach opens a new angle on strategic management theory. For management researchers, the results suggest that supply chain management is an integral part of strategic management.

Finally, results of the research have been embodied in some practical implications. Determining the focal enterprises of the network and defining their characteristics will help in redesigning the network, especially in crisis situations. These situations can include, of course, the lengthy crisis over Covid-19 and its consequences, which will certainly not end, especially in some sectors, in a few months' time (and will not return to its original status for several years). If the existing key member of the network needs to be replaced by another company due to its poor financial health or the impossibility of its functioning by government restrictions, knowledge of possible successors is crucial for the survival of the network. It can be expected that the networks will behave according to the following two scenarios: 1 . specialization - i.e. a reduction in the number of suppliers and with it a reduction in the number of networks in which companies operate. To survive and be more robust thanks to stronger ties and flows (and they will kind of hope that their industry will not take it away next time): 2 . the extension of the scope - as a safeguard against the restriction of one part of the production spectrum, to expand the production program and thus participate in other networks and cooperation with other suppliers. Moreover, perhaps mastering them will be the key to overcoming the difficult situation facing not only the Czech Republic. 
Future research directions are related to the conditions, factors, and variables that affect the division of roles and power networks. A potential area for further research is applying and using new technologies (such as blockchain) that virtualize relationships and connections into a digital form. Although these tendencies may not yet be apparent from the research findings, it is appropriate to focus on them. A very interesting future research area could be a case study focusing on the supply chains in the agri-food and automotive industry, which would uncover differences between the " $\wedge$ " and "V" type of networks structures in more details.

\section{Acknowledgment}

This paper was supported by the University of South Bohemia in Ceske Budejovice under EF-IGS2020-Pech-5 Grant "Industry 4.0 and Supply Chain Management".

\section{References}

Achrol, R. S., \& Kotler, P. (1999). Marketing in the Network Economy. Journal of Marketing, 63, 146-163. https://doi.org/10.2307/1252108

Adhikary, A., Sharma, A., Diatha, K. S., \& Jayaram, J. (2020). Impact of buyersupplier network complexity on firms' greenhouse gas (GHG) emissions: An empirical investigation. International Journal of Production Economics, 230, 107864. https://doi.org/10.1016/j.ijpe.2020.107864

Akyuz, G. A., \& Gursoy, G. (2020). Strategic management perspectives on supply chain. Management Review Quarterly, 70(2), 213-241. https:// doi.org/10.1007/s11301-019-00165-6

Ashnai, B., Smirnova, M., Henneberg, S. C., \& Naudé, P. (2019). Dyadic operationalization in business relationships: The empirical example of marketing-purchasing collaboration. Journal of Business-toBusiness Marketing, 26(1), 19-42. https://doi.org/10.1080/105171 2X.2019.1565134

Bellamy, M. A., Ghosh, S., \& Hora, M. (2014). The influence of supply network structure on firm innovation. Journal of Operations Management, 32(6), 357-373. https://doi.org/10.1016/j.jom.2014.06.004

Berger, P. D., Gerstenfeld, A., \& Zeng, A. Z. (2004). How many suppliers are best? A decision-analysis approach. Omega, 32(1), 9-15. https://doi. org/10.1016/j.omega.2003.09.001

Bode, Ch., \& Wagner, S. M. (2015). Structural drivers of upstream supply chain complexity and the frequency of supply chain disruptions. Journal of Operations Management, 36, 215-228. https://doi.org/10.1016/j. jom.2014.12.004 
Borgatti, S. P., \& Li, X. (2009). On social network analysis in a supply chain context. Journal of Supply Chain Management, 45(2), 5-22. http://dx.doi. org/10.2139/ssrn.2260994

Bozarth, C. C., Warsing, D. P., Flynn, B. B., \& Flynn, E. J. (2009). The impact of supply chain complexity on manufacturing plant performance. Journal of Operations Management, 27(1), 78-93. https://doi.org/10.1016/j. jom.2008.07.003

Burt, R. S. (2004). Structural holes and good ideas. American Journal of Sociology, 110(2), 349-399. https://doi.org/10.1086/421787

Calderon, M. A., Roark, G., Urrutia, S., Paravie, D., \& Rohvein, C. (2017). Methodology for the Supply Chain's classification and diagnosis. Revista Ciencias Estrategicas, 25(38), 279-298. https://doi.org/10.18566/rces. v25n38.a2

Castells, M. (2010). The Rise of the Network Society: The Information Age: Economy, Society, and Culture. Hoboken: Wiley-Blackwell.

Chen, H. Y. S., Lin, C. W. R., \& Yih, Y. (2007). Production-distribution network design of a global supply chain alliance from the key player's perspective. International Journal of Production Research, 45(2), 245-265. https:// doi.org/10.1080/00207540600623835

Cheng, Ch.-Y., Chen, T.-L., \& Chen, Y.-Y. (2014). An analysis of the structural complexity of supply chain networks. Applied Mathematical Modelling, 38(9), 2328-2344. https://doi.org/10.1016/j.apm.2013.10.016

Choi, T.Y., \& Kim, Y. (2008). Structuralembeddednessand suppliermanagement: A network perspective. Journal of Supply Chain Management, 44(4), 5-13. https://doi.org/10.1111/j.1745-493X.2008.00069.x

Choi, T. Y., \& Wu, Z. (2009). Triads in supply networks: Theorizing buyersupplier-supplier relationships. Journal of Supply Chain Management, 45(1), 8-25. http://dx.doi.org/10.1111/j.1745-493X.2009.03151.x

Christopher, M. (2016). Logistics and Supply Chain Management (5th ed.). New York: Pearson Education.

Christopher, M., \& Ryals, L. J. (2014). The supply chain becomes the demand chain. Journal of Business Logistics, 35(1), 29-35. https://doi. org/10.1111/jbl.12037

Clarke, M. P. (1998). Virtual logistics: An introduction and overview of the concepts. International Journal of Physical Distribution \& Logistics Management, 28(7), 486-507. https://doi. org/10.1108/09600039810247461

Croom, S, Romano, P., \& Giannakis, M. (2000). Supply chain management: An analytical framework for critical literature review. European Journal of Purchasing \&amp; Supply Management, 6(1), 67-83. http://dx.doi. org/10.1016/S0969-7012(99)00030-1

Czakon, W. (2016). Network strategies logic. Problemy Zarządzania, 14(4), 1730. https://doi.org/10.7172/1644-9584.64.1

Czech Statistical Office. (2019). Ekonomické subjekty podle převažující činnosti CZ-NACE v České republice [Economic entities: by prevailing CZ- 
NACE activity in the Czech Republic]. Retrieved from https://vdb.czso.cz/ vdbvo2/

Danese, P. (2011). Towards a contingency theory of collaborative planning initiativesinsupply networks. InternationalJournalofProduction Research, 49(4), 1081-1103. https://doi.org/10.1080/00207540903555510

De Felice, F., Petrillo, A., \& Autorino, C. (2015). Development of a framework for sustainable outsourcing: Analytic Balanced Scorecard Method (A-BSC). Sustainability, 7(7), 8399-8419. https://doi.org/10.3390/su7078399

European Commission. (2003). Recommendation of 6 May 2003 Concerning the Definition of Micro, Small and Medium-Sized Enterprises (Text with EEA Relevance). Notified under Document Number C (2003) 1422. Luxembourg: The Publications Office of the European Union.

Fawcett S, E. (2002). The rhetoric and reality of supply chain integration. InternationalJournalofPhysicalDistribution \&amp; LogisticsManagement, 32(5), 339-361. https://doi.org/10.1108/09600030210436222

Field, A., Miles, J., \& Field, Z. (2012). Discovering Statistics Using R. London: Sage Publications Ltd.

Frohlich, M. T., \& Westbrook, R. (2001). Arcs of integration: An international study of supply chain strategies. Journal of Operations Management, 19(2), 185-200. https://doi.org/10.1016/s0272-6963(00)00055-3

Gibbons, E. D. (2007). Interorganizational network structures and diffusion of information through a health system. American Journal of Public Health, 97(9), 1684-1692. https://doi.org/ 10.2105/AJPH.2005.063669

Gomes-Casseres, B. (1996). The Alliance Revolution. Cambridge: Harvard University Press.

González-López, M. (2012). The Spanish cod fishing industry: Radical production changes without significant changes in the innovation system. Journal of Entrepreneurship, Management and Innovation, 8(4), 35-51. https://doi.org/ 10.7341/2012843

Govindan, K., Fattahi, M., \& Keyvanshokooh, E. (2017). Supply chain network design under uncertainty: A comprehensive review and future research directions. European Journal of Operational Research, 263(1), 108-141. https://doi.org/10.1016/j.ejor.2017.04.009

Gulati, R. (1998). Alliances and networks. Strategic Management Journal, 19(4), 293-317. https://doi.org/10.1002/(sici)10970266(199804)19:4<293::aid-smj982>3.0.co;2-m

Gulati, R., Nohria, N., \& Zaheer, A. (2000). Strategic networks. Strategic Management Journal, 21(3), 203-215. https://doi.org/10.1002/ (sici)1097-0266(200003)21:3<203::aid-smj102>3.0.co;2-k

Guo, J. L. (2006). Bilateral power-law distribution model of supply chain network. Acta Physica Sinica -Chinese Edition, 55(8), 3916-3921. https:// doi.org/10.7498/aps.55.3916

Håkansson, H., \& Ford, D. (2002). How should companies interact in business networks? Journal of Business Research, 55(2), 133-139. https://doi. org/10.1016/s0148-2963(00)00148-x 
Håkansson, H., \& Snehota, I. (1995). Developing Relationships in Business Networks. London: Routledge.

Handfield, B. R., \& Nichols, L. E. (1999). Introduction to Supply Chain Management. New Jersey: Prentice-Hall.

Harland, C. M. (1996). Supply chain management: Relationships, chains and networks. British Journal of Management, 7, 63-S80. https://doi. org/10.1111/j.1467-8551.1996.tb00148.x

Hasani, A., \& Khosrojerdi, A. (2016). Robust global supply chain network design under disruption and uncertainty considering resilience strategies: A parallel memetic algorithm for a real-life case study. Transportation Research Part E-Logistics and Transportation Review, 87, 20-52. https:// doi.org/10.1016/j.tre.2015.12.009

Hearnshaw, E. J. S., \& Wilson, M. M. J. (2013). A complex network approach to supply chain network theory. International Journal of Operations \& Production Management, 33(3-4), 442-469. 10.1108/01443571311307343

Heydari, J., Zaabi-Ahmadi, P., \& Choi, T. M. (2018). Coordinating supply chains with stochastic demand by crashing lead times. Computers \& Operations Research, 100, 394-403. https://doi.org/10.1016/j.cor.2016.10.009

Hingley, M., Lindgreen, A., Grant, D. B., \& Kane, C. (2011). Using fourthparty logistics management to improve horizontal collaboration among grocery retailers. Supply Chain Management-an International Journal, 16(5), 316-327. https://doi.org/10.1108/13598541111155839

Holm, S. (1979). A Simple Sequentially Rejective Multiple Test Procedure. Scandinavian Journal of Statistics, 6(2), 65-70. Retrieved from: https:// www.jstor.org/stable/4615733

Hult, G. T. M., Ketchen, D. J., \& Arrfelt, M. (2007). Strategic supply chain management: Improving performance through a culture of competitiveness and knowledge development. Strategic Management Journal, 28(10), 1035-1052. https://doi.org/10.1002/smj.627

lurkov, V., \& Benito, G. R. G. (2018). Domestic alliance networks and regional strategies of MNEs: A structural embeddedness perspective. Journal of International Business Studies, 49(8), 1033-1059. https://doi. org/10.1057/s41267-017-0089-5

Jarillo, J. C. (1988). On strategic networks. Strategic Management Journal, 9(1), 31-41. https://doi.org/10.1002/smj.4250090104

Jia, F., Gong, Y., \& Brown, S. (2018). Multi-tier sustainable supply chain management: The role of supply chain leadership. International Journal of Production Economics. https://doi.org/10.1016/j.ijpe.2018.07.022

Jung, H. S., \& Jeong, B. (2005). Decentralized production-distribution planning system using collaborative agents in supply chain network. International Journal of Advanced Manufacturing Technology, 25(1-2), 167-173. https://doi.org/10.1007/s00170-003-1792-x 
Ketchen,D.J.,\&Giunipero,L.C.(2004).Theintersection of strategicmanagement and supply chain management. Industrial Marketing Management, 33(1), 51-56. https://doi.org/10.1016/j.indmarman.2003.08.010

Klincewicz, K. (2012). Political perspective on technology alliances - The cases of Microsoft and Google. Journal of Entrepreneurship, Management and Innovation, 8(1), 5-34. https://doi.org/10.7341/2012811

Koch, T., \& Windsperger, J. (2017). Seeing through the network: Competitive advantage in the digital economy. Journal of Organization Design, 6(6), 1-30. https://doi.org/10.1186/s41469-017-0016-z

Krzakiewicz, K., \& Cyfert, S. (2013). The network concept of strategic management and its limitations. Management, 17(1), 19-30. https://doi. org/10.2478/manment-2013-0002

Lambert, D. M., \& Cooper, M. C. (2000). Issues in supply chain management. Industrial Marketing Management, 29(1), 65-83. https://doi. org/10.1016/s0019-8501(99)00113-3

Lu, G., \& Shang, G. (2017). Impact of supply base structural complexity on financial performance: Roles of visible and not-so-visible characteristics. Journal of Operations Management, 53-56, 23-44. https://doi. org/10.1016/j.jom.2017.10.001

Mentzer, J. T., DeWitt, W., Keebler, J.S., Min, S., Nix, N. W., Smith, C. D., \&Zacharia, Z. G. (2001). Defining supply chain management. Journal of Business Logistics, 22(2), 1-25. https://doi.org/10.1002/j.2158-1592.2001. tb00001.x

Modrak, V., \& Bednar, S. (2016). Topological complexity measures of supply chain networks. Procedia CIRP, 40, 295-300. https://doi.org/10.1016/j. procir.2016.01.041

Moller, K. K., \& Halinen, A. (1999). Business relationships and networks: Managerial challenge of network era. Industrial Marketing Management, 28(5), 413-427. https://doi.org/10.1016/s0019-8501(99)00086-3

Nalebuff, B. J., \& Brandenburger, A. M. (1997). Co-opetition: Competitive and cooperative business strategies for the digital economy. Strategy \& Leadership, 25(6), 28-33. https://doi.org/10.1108/eb054655

Özceylan, E., Demirel, N., Çetinkaya, C., \& Demirel, E. (2017). A closed-loop supply chain network design for automotive industry in Turkey. Computers \& Industrial Engineering, 113, 727-745. https://doi.org/10.1016/j. cie.2016.12.022

Parker, R., \& Cox, S. (2013). Power relations and small and medium- sized enterprise strategies for capturing value in global production networks: Visual Effects (VFX) service firms in the Hollywood film industry. Regional Studies, 47(7), 1095-1110. https://doi.org/10.1080/00343404.2011.600 303

Pech, M., \& Vanecek, D. (2020). Supplier performance management in context of size and sector characteristics of enterprises. Quality Innovation Prosperity-Kvalita Inovacia Prosperita, 24(1), 88-103. https:// doi.org/10.12776/qip.v24i1.1407 
Pibernik, R., \& Sucky, E. (2006). Centralized and decentralized supply chain planning. International Journal of Integrated Supply Management, 2(1/2), 6-27. https://doi.org/10.1504/IJISM.2006.008336

Pražáková, J., \& Pech, M. (2019). The identification of the Key players in the supply chain networks. In Proceedings of the 37th International Conference on Mathematical Methods in Economics 2019 (pp. 326330). Ceske Budejovice, Czech Republic: University of South Bohemia in Ceske Budejovice. Retrieved from https://www.researchgate.net/ publication/335972435_The_identification_of_the_Key_players_in_ the_supply_chain_network

Rifkin, J. (2000). The Age of Access: The New Culture of Hypercapatalism. New York: J P Tarcher/Putnam.

Roelich, K., Knoeri, Ch., Steinberger, J. K., Varga, L., Blythe, P. T., Butler, D., Gupta, R., Harrison, P. G., Martin, Ch., \& Purnell, P. (2015). Towards resource-efficient and service-oriented integrated infrastructure operation. Technological Forecasting and Social Change, 92, 40-52. https://doi.org/10.1016/j.techfore.2014.11.008

Rudberg, M., \& West, M. B. (2008). Global operations strategy: Coordinating manufacturing networks. Omega, 36(1), 91-106. https://doi. org/10.1016/j.omega.2005.10.008

Ruiz-Torres, A. J., \& Mahmoodi, F. (2007). The optimal number of suppliers considering the costs of individual supplier failures. Omega, 35(1), 104115. https://doi.org/10.1016/j.omega.2005.04.005

Scott-Kennel, J., \& Saittakari, I. (2020). Sourcing or sharing in MNE networks? National headquarters and foreign subsidiaries as knowledge conduits in SMOPECs. International Business Review, 29(1). https://doi. org/10.1016/j.ibusrev.2019.101622

Shin, H. J. (2007). Collaborative production planning in a supply-chain network with partial information sharing. International Journal of Advanced Manufacturing Technology, 34(9-10), 981-987. https://doi.org/10.1007/ s00170-006-0664-6

Simangunsong, E. (2015). Analyzing parallel interaction in supply chains: a supply chain network perspective. 2015, 6(3). https://doi.org/10.21632/ irjbs.6.3.171-184

Simon, H. A. (1972). Theories of bounded rationality. Theories of Bounded Rationality, 161-176. Retrieved from https://www.researchgate.net/ profile/David_Rine2/post/Is_it_logical_to_say_real_number_set_has_ more_elements_than_natural_number_set_so_real_number_set_is more_infinite_than_natural_number_set/attachment/59d63d9bc49f4 $\overline{7}$ 8072ea895f/AS\%3A273761733939219\%401442281291913/download/ Herb+Simon-Theoriesof+Bounded+Rationality.pdf

Smolová, J. (2008). Analysis of small and middle size enterprises approaches to suppliers. Acta Universitatis Bohemiae Meridionalis, 11(3), 31-38. Retrieved from https://ideas.repec.org/a/boh/actaub/ v11y2008i3p31-38.html 
Sudolska, A., \& Lis, A. (2014). Building a model of successful collaborative learning for company innovativeness. Journal of Entrepreneurship, Management and Innovation, 10(3), 109-137. https://doi.org/ $10.7341 / 20141035$

Sun, J., \& Debo, L. (2014). Sustaining long-term supply chain partnerships using price-only contracts. European Journal of Operational Research, 233(3), 557-565. https://doi.org/10.1016/j.ejor.2013.09.020

Światowiec-Szczepańska, J., \& Kawa, A. (2018). Metafory, modele i teorie sieci w naukach o zarządzaniu. Organizacja i Kierowanie, 2(281), 7991. Retrieved from https://ssl-kolegia.sgh.waw.pl/pl/KZiF/czasopisma/ oik/numery/Documents/2018_2_181/swiatowiec-szczepanska-kawametafory-modele-i-teorie-sieci-w-naukach-o-zarzadzaniu.pdf

Szozda, N. (2017). Industry 4.0 and its impact on the functioning of supply chains. Logforum, 13(4), 401-414. https://doi.org/10.17270/j. $\log .2017 .4 .2$

Tikkanen, J., \& Halinen, A. (2003). Network approach to strategic management - exploration to the emerging perspective. Paper presented at the 19th Annual IMP Conference, Lugano, Switzerland. Retrieved from http:// www.impgroup.org/paper_view.php?viewPaper $=4430$

Venus, K. (2014). Supply Chain management-part of strategic management Journal of Business and Economics, 5(7), 1052-1067. https://doi. org/10.15341/jbe(2155-7950)/07.05.2014/010

Vrchota, J., \& Pech, M. (2019). Readiness of enterprises in Czech Republic to implement Industry 4.0: Index of Industry 4.0. Applied Sciences, 9(24), 1-25. https://doi.org/10.3390/app9245405

Wan, J., Tang, S., Li, D., Wang, S., Liu, C., Abbas, H., \& Vasilakos, A. V. (2017). A manufacturing big data solution for active preventive maintenance. IEEE Transactions on Industrial Informatics, 13(4), 2039-2047. https:// doi.org/10.1109/TII.2017.2670505

Wang, S., Wan, J.,Li, D., \& Zhang, Ch. (2016). Implementing smart factory of Industrie 4.0: An outlook. International Journal of Distributed Sensor Networks, 12(1), 1-10. https://doi.org/10.1155/2016/3159805

Wasserman, S, \& Faust, K. (1995). Social Network Analysis. Methods and Applications. London: Cambridge University Press.

Wei, Y, Wang, H., \& Chen, F. (2015). Exploring the impact of network structure and demand collaboration on the dynamics of a supply chain network using a robust control approach. Mathematical Problems in Engineering, 21(1), 1-13. http://dx.doi.org/10.1155/2015/102727

Wen, T., \& Jiang, W. (2019). Measuring the complexity of complex network by Tsallis entropy. Physica A: Statistical Mechanics and its Applications, 526, 121054. https://doi.org/10.1016/j.physa.2019.121054

Wynstra, F. (1994). Strategic actions in networks - the concept of position. In W. Biemans \& P. Ghauri (Eds.), Industrial Marketing and Purchasing Group Conference; Refereed papers from the 10th Industrial Marketing 
and Purchasing Group Conference (pp.802-817). Groningen, The Netherlands: IMP Group.

Yamada, K. (2019). Inter-firm relationships and leverage adjustment. Research in International Business and Finance, 50, 381-391. https://doi. org/10.1016/j.ribaf.2019.06.006

Yli-Huumo, J., Ko, D., Choi, S., Park, S., \& Smolander, K. (2016). Where is current research on blockchain technology? A systematic review. Plos One, 11(10). https://doi.org/10.1371/journal.pone.0163477

Zhong, R., Wang, L., \& Xu, X. (2017). Food supply chain management: Systems, implementations, and future research. Industrial Management \& Data Systems. 117(9), 2085-2114. https://doi.org/10.1108/IMDS-092016-0391

\begin{abstract}
Abstrakt
CEL: Obecne badania majq na celu stworzenie modelu ekonomicznego, który łączy zarzqdzanie strategiczne i teorię sieci. Jednakże większość modeli teoretycznych nie dostarcza empirycznych dowodów rzeczywistej struktury i atrybutów relacji sieciowych. Celem artykułu jest zbadanie zależności między cechami przedsiębiorstwa a charakterystykq relacji nabywca-dostawca w sieciach łańcuchów dostaw. Jesteśmy szczególnie zainteresowani relacjami biznesowymi w sieciach z uwzględnieniem różnych wielkości przedsiębiorstw i sektorów przemysłu. W artykule podsumowano wyniki badań empirycznych nad sieciami kupiec-dostawca oraz podkreślono znaczenie rozwijania i wspierania współpracy biznesowej dla zarzqdzania strategicznego. Artykuł podsumowuje wyniki badań empirycznych dotyczq̨ych sieci nabywców i dostawców oraz podkreśla znaczenie rozwoju i wspierania współpracy biznesowej w zarzqdzaniu strategicznym. METODYKA: Badanie ankietowe przeprowadziliśmy w latach 2016-2018 na 360 przedsiębiorstwach z Czech. Próbę badawczq dobrano w oparciu o metodę celowego pobierania próby. Członkowie zespołu badawczego zebrali dane z ankiety internetowej i osobistych wizyt w przedsiębiorstwach. Analiza statystyczna hipotez opiera się na częstotliwości odpowiedzi menedżerów. Aby ocenić wyniki, stosuje się test $Z w$ dwóch proporcjach do porównywania różnych kategorii przedsiębiorstw zgodnie z ich wielkościq lub dominujqcym sektorem przemysłu. WYNIKI: Główne wyniki pokazujq, że różnice między przedsiębiorstwami zaangażowanymi w struktury nabywca-dostawcy wynikaja głównie z ich wielkości. Badanie nie wykazało różnic między sektorami przemysłu. Wyniki pokazujq, że złożoność sieci w Republice Czeskiej nie jest duża pod względem liczby dostawców lub zaangażowania w wiele sieci dostaw. Ciqgłość relacji z partnerami w sieciach nabywców i dostawców ma charakter stosunkowo długofalowy. Długoterminowe partnerstwa odzwierciedlajq wyższq jakość relacji i wspieraja przyszłq integrację. Jednak duże przedsiębiorstwa wolq budować kontrakty na krótsze lub dłuższe okresy. Ogólna strategia decentralizacji charakteryzuje zarzqdzanie strategiczne sieciami nabywców i dostawców. Odkrycie to oznacza podziat kompetencji, takich jak planowanie, zarzqdzanie, pozyskiwanie, podejmowanie decyzji, transport (dostarczanie) między przedsiębiorstwami. IMPLIKACJE DLA TEORII I PRAKTYKI: Artykuł zapewnia wglqad w zrozumienie, jak działa sieć nabyw-
\end{abstract}


ca-dostawca. Opiera się na połq̨czeniu zarzqdzania łańcuchem dostaw i zarzq̨dzania strategicznego z perspektywy sieci. Zarzqdzanie tańcuchem dostaw postrzegane jest jako część zarzqdzania strategicznego, a synteza obu obszarów badawczych otwiera innowacyjne spojrzenie na teorię biznesu. ORYGINALNOŚĆ I WARTOŚć: Zasadniczq wartościq pracy jest powiqzanie współczesnych idei zarzqdzania strategicznego i zarzq̨dzania łańcuchem dostaw. Synteza zarzqdzania łańcuchem dostaw i podejście sieciowe wzmacnia teorię zarzqdzania strategicznego.

Słowa kluczowe: sieć, relacje kupiec-dostawca, zarzqdzanie strategiczne, złożoność, ciqgłość, zarzq̨dzanie łańcuchem dostaw

\section{Biographical notes}

Martin Pech is senior assistant professor at the University of South Bohemia in Ceske Budejovice, Faculty of Economics, Department of Management, Czech Republic. His research interests include Industry 4.0, lean manufacturing, supply chain networks, and strategic management.

Drahoš Vaněček has over 60 years' experience in research, teaching, and practice in logistics and operations management. He has served for 28 years as professor at the University of South Bohemia in Ceske Budejovice, Faculty of Economics, Department of Management, Czech Republic. His current research interests are related to logistics, supply chain management, transport management, and lean production.

Jaroslava Pražáková is senior assistant professor of the Department of Accounting and Finance Faculty of Economics, University of South Bohemia in Ceske Budejovice. Her research interests are focused mainly on corporate finance, supply chain networks, and strategic management.

\section{Conflicts of interest}

The authors declare no conflict of interest.

\section{Citation}

Pech, M., Vaněček, D., \& Pražáková, J. (2021). Complexity, continuity, and strategic management of buyer-supplier relationships from a network perspective. Journal of Entrepreneurship, Management and Innovation, 17(3), 189-226. https://doi.org/10.7341/20211736 